\author{
Mugilan Poongkunran ${ }^{*}$ and Asad \\ Javaid
}

Department of Medicine, Gastroenterology Division Beth Israel Deaconess Medical Center, Harvard Medical School, Boston, Massachusetts, USA

Dates: Received: 03 August, 2015; Accepted: 29 August, 2015; Published: 01 September, 2015

*Corresponding author: Mugilan Poongkunran, Department of Medicine, Gastroenterology

Division, Beth Israel Deaconess Medical Center, Harvard Medical School, 110 Francis Street, LMOB

Suite 4A, Liver Research Center, Boston 02215,

Massachusetts, USA, Tel: +1-347-896-3626; Fax: +1-

617-632-1125; E-mail: mpoongku@bidmc.harvard.edu

www.peertechz.com

ISSN: 2455-2283

Keywords: Chronic hepatitis B; Interferon; Entecavir; Tenofovir; Hepatocellular carcinoma

\author{
Review Article
}

\section{A Review on Therapeutic Management of Chronic Hepatitis B Infection}

\section{Abbreviations}

CHB: Chronic Hepatitis B; PEG-IFNa: Pegylated Interferon-alfa; NA's: Nucleos(t)ide Analogues; ETV: Entecavir; TDF: Tenofovir; HCC: Hepatocellular Carcinoma; SVR: Sustained Virological Response; ALT: Alanine Aminotransferase;

\section{Introduction}

Chronic hepatitis $\mathrm{B}(\mathrm{CHB})$ infection is defined at large by the presence of hepatitis B surface antigen (HBsAg) for more than 6 months; though some patients may test positive only for anti-HBc without HBsAg or anti-HBs [1]. An estimated 240 million people are chronically infected with hepatitis B and a $15 \%$ to $40 \%$ lifetime risk of death exist in these affected population due to serious sequelae such as cirrhosis, hepatic decompensating, and hepatocellular carcinoma (HCC) $[1,2]$. The increasing prevalence, morbidity and mortality of $\mathrm{CHB}$ can be linked to its diverse and variable natural course; which in general, is serologically illustrated either by the presence or absence of hepatitis B virus (HBV) e antigen ( $\mathrm{HBeAg}$ ) indicating earlier and late phases of the disease, respectively [3,4]. The ultimate goal of $\mathrm{CHB}$ therapy is to arrest the progression of liver injury and to prevent the development of liver failure, HCC and hence liver transplantation. Despite the advent of potent anti-HBV agents such as interferonalpha (INFa) and nucleos(t)ide analogues (NA's), the current management is majorly ineffective in eradicating the virus, providing only apparent virological suppression $[3,5]$. Hence an absolute cure or functional cure, where the risk of death from liver disease is same as a person who was never infected or same as a person with naturally resolved infection, remains impracticable yet [5]. Also, though the existing practice guidelines such as that of American Association for the Study of Liver Diseases (AASLD), European Association for the Study of the Liver (EASL), and Asian Pacific Association for the Study of the Liver (APASL) assist physicians in the diagnosis and optimal management of $\mathrm{CHB}$; they are still expected to individualize the management considering various factors like cost-effectiveness, compliance, efficacy and duration of anti-viral agents, existence of coinfections etc. $[1,3,4]$. This article reviews the basis for those guideline recommendations, the natural history of the disease, treatment options and what we do in our practice to illustrate factors that may influence the management of $\mathrm{CHB}$.

\section{Natural history of chronic hepatitis B infection}

Continuous advances have been made in understanding the natural history of the disease, which is majorly determined by the interplay between host-immune responses and viral replication. Such knowledge and identification of which natural history phase of the disease the patients are in would be the ideal first step in the management of $\mathrm{CHB}$ infection, as the criteria and endpoints of treatment differ accordingly. The dynamic natural course of $\mathrm{CHB}$ infection can be categorized into at least five phases; however, these need not be in sequence and exist in all patients with the disease [6].

- The initial phase is characterized by high levels of HBV replication with no evidence of active liver disease and hence termed as "high replicative, low inflammatory phase". This phase is more common in patients with prenatally acquired $\mathrm{CHB}$ infection and is widely known as the "immune tolerant phase", for the inability of immature immune system to 
identify the virus aided by the HBeAg protein $[1,3]$. However, researchers state a hypothesis of trained immunity, evidenced by enhanced innate immune cell maturation and Th1 development resulting in a similar $\mathrm{T}$ cell response to that seen in the immune clearance phase of $\mathrm{CHB}[7,8]$. These immune trained $\mathrm{HBeAg}$ positive patients are characterized by very high levels of serum HBV DNA that is commonly above $20,000 \mathrm{IU} / \mathrm{mL}$ or 1 million $\mathrm{IU} / \mathrm{mL}$, normal to low levels of serum aminotransferases, and no to minimal liver necroinflammation and fibrosis [1,3]. During this phase, the reverse transcriptase properties of HBV may support its integration randomly into the host hepatocyte DNA resulting in persistently elevated HBV DNA levels over many years; thereby increasing the risk of cirrhosis and HCC.

- In the "immune clearance phase", the host's immune system initiate it's response to HBV resulting in hepatocyte injury. It is more common and rapidly reached in patients infected during adulthood resulting in spontaneous HBeAg clearance, paralleling the maturity of innate and adaptive immune responses. Patients early in this phase are mostly $\mathrm{HBeAg}$ positive, with high levels of serum HBV DNA, elevated levels of serum aminotransferases, and moderate to severe liver necro-inflammation with more progression to fibrosis $[1,3]$. Over the time, in many cases spontaneous $\mathrm{HBeAg}$ clearance occurs, accompanied with exacerbations in serum alanine aminotransferases (ALT) and HBV DNA levels [9]. This phase ends with the appearance of anti-Hbe and such clearance either spontaneously or by antivirals during early stages of the disease has been shown to significantly reduce the risk of complications [3].

- Patients in the "HBeAg-negative CHB phase" have HBV virions in the precore and/or the basal core promoter regions with nucleotide substitutions. These patients are generally characterized by $\mathrm{HBeAg}$ negativity, with periodic reactivation due to ineffective immune clearance, resulting in moderate to high levels of viral load (usually $>2000$ IU/ $\mathrm{ml}$ ) and aminotransferases levels [1,3]. The serum HBV DNA and ALT levels are much lower compared to $\mathrm{HBeAg}$ positive individuals in the immune clearance phase. They have continued necro-inflammation in the liver and are at risk of complications due to low rates of prolonged remissions.

- Predominantly patients in the "non-replicative phase"; widely known as "inactive $H B V$ carrier" phase, are characterized by seroconversion of $\mathrm{HBeAg}$ to anti-Hbe, very low or undetectable serum HBV DNA levels (usually <2000 IU/ $\mathrm{ml}$ ) and normal serum aminotransferases (approximately $40 \mathrm{IU} / \mathrm{m}$ ) conferring a favorable long-term outcome due to immunological control of the infection $[3,6]$. However, care should be taken in categorizing these patients as inactive carriers with minimum three consecutive serological readings over a 12-month period of observation.

- Patients in the "occult HBV phase" are defined by the loss of the hepatitis B surface antigen, hence also termed as " $H B s A g$ negative phase". However, a low level of HBV replication persist in the liver, characterized by intrahepatic presence of cccDNA chromatinized episomes. Most patients in this phase have very low to undetectable HBV DNA levels, with anti-HBc and with or without anti-HBs. Generally they have a better prognosis, if HBsAg loss occurs before the onset of cirrhosis $[3,6]$.

\section{Factors related to chronic hepatitis B progression}

The clinical scenario following hepatitis B infection is determined by the interplay of other associated factors such as sex, age, genotypes, co-infections, alcohol consumption etc. Hence its consideration should always be taken prior to the initiation of therapy for $\mathrm{CHB}$.

Genotype: To date, 10 genotypes (A through J) have been reported across different geographic regions and numerous studies have revealed their clinical importance on the chronicity of the disease, response to therapy and progression to complications. Genotype $\mathrm{C}$, which is common in Asian population, have been shown to be associated with the longest average age of HBeAg seroconversion; thereby carrying the highest risk for HCC than any other genotypes [10]. Genotype B is regularly divided into Bj (B1 and B6, found in japan) and $\mathrm{Ba}$ (B2-5, found in rest of Asia) sub-types. The genome of $\mathrm{Ba}$ group has a portion of genotype $\mathrm{C}$ genome; thereby making these people prone for complications and basal core promoter (BCP) mutations than those with $\mathrm{Bj}$ [11]. Persons infected with genotype D, which is common in Eastern Europe, Southern Europe and Middle East; have been shown to go frequently into either "HBeAg-negative CHB phase", harboring precores variants with high risk for HCC or into "inactive HBV carrier" with low risk for complications $[12,13]$. Genotype A, which is classified into A1 and A2, is widespread in Western Africa, sub-Saharan Africa and Northern Europe. Genotype Al is associated with HCC in HBeAg negative young patients with low HBV DNA levels and cirrhosis rate [13]. Though, genotype A2 is associated with HCC in older persons, its risk is comparatively lower to genotype D with higher clearance of HBsAg [14]. Across different genotypes, though treatment response to nucleos(t)ide analogues have been reported to be similar, genotypes $A$ and $B$ have shown better response rates to interferon substitutes than genotypes C, D $[15,16]$. The recently included genotypes are genotype I and J, reported in Vietnam, Laos and in Ryukyu islands of Japan, respectively $[17,18]$. However, its clinical importance is not yet clearly studied.

Age: Persons who are infected via perinatal transmission from HBeAg-positive mothers tends to be in the "high replicative, low inflammatory phase" phase of the disease for a longer duration. These young infected individuals are associated with lower rate of clearance of $\mathrm{HBeAg}$ and poor prognosis, compared to the older individuals [19].

Co-infections: Patients with chronic hepatitis B may be coinfected with more than one genotype or with other viruses. Though studies have demonstrated co-infections with different HBV genotypes, it's clinical consequences still remains unclear [20]. Coexistent hepatitis $\mathrm{C}$ virus (HCV) infection is mostly either acute co-infection of $\mathrm{HCV}$ and $\mathrm{HBV}$, or acute $\mathrm{HCV}$ on preexisting chronic $\mathrm{HBV}$; where HCV becomes the dominant virus and suppresses HBV DNA levels. However, both these presentations have been reported 
to increase the risk of severe hepatitis, fulminant hepatic failure, cirrhosis and HCC development compared to patients infected by either virus alone [21]. Hepatitis delta virus (HDV) is an incomplete RNA virus that obliges the presence of HBV within the hepatocytes to complete its assembly and replication. Such interactions either presents as a co-infection with $\mathrm{HBV}$ or as super-infection occurring in chronic HBV carriers. However, on contrary to HCV co-infection with HBV, HDV co-infection is usually transient and self-limited, with rates of chronicity and complications similar to HBV monoinfected patients [22]. Super-infection with HDV, in most cases presents as self-limiting severe acute hepatitis with establishment of HDV chronicity and exacerbation of the pre-existing HBV chronicity [23]. Co-infection of HBV with HIV is a rising global health problem with lower rates of spontaneous $\mathrm{HBeAg}$ seroconversion, and hence the serious sequelae. Also, these patients may have occult HBV infections characterized by the presence of anti-HBc, high HBV DNA levels, without HBsAg [24].

NASH/NAFLD: Non-alcoholic fatty liver disease (NAFLD) or non-alcoholic steatohepatitis (NASH) is an important cause of chronic liver disease, with increasing prevalence paralleling to the global rise of obesity, insulin resistance, and type 2 diabetes mellitus (T2DM). Studies analyzing NAFLD or NASH in chronic hepatitis B patients have shown its added impact on the development of fibrosis [25].

Cirrhosis: Several studies have shown the strong associations between HBeAg and high levels of HBV DNA to the development of cirrhosis. Also, though cirrhosis is an independent risk factor for HCC, its absence doesn't rule out the development of the HCC in CHB patients [26].

Mutations: Several prospective studies have established that, BCP mutation [adenine (A) to thymine $(\mathrm{T})$ transversion at nucleotide 1762 together with a guanine $(\mathrm{G})$ to adenine $(\mathrm{A})$ transition at nucleotide 1764 ] and precore mutation [nucleotide 1896 mutation from guanine (G) to adenine (A)] are independent risk factors for HCC in CHB patients even after adjusting for their genotypes. On the other hand, the presence of the PC mutation was associated with a lower risk of developing HCC [27].

\section{Available treatment options}

The U.S. Food and Drug Administration (FDA) have approved seven agents for the treatment of CHB [28]. The first licensed agent for the treatment of chronic HBV infection was the conventional form of interferon alfa (in 1991); which have antiviral, antiproliferative, and immunomodulatory effects. Pegylated interferon (PEGIFNa), an agent that is almost identical to that of standard IFNa, was licensed in 2005. Other agents that are currently in use are nucleoside and nucleotide analogues; which are pure anti-virals that act via suppression of $\mathrm{HBV}$ replication through inhibition of the reverse transcriptase and DNA polymerase activities. Lamivudine, a nucleoside analogue, was the first among them to be licensed in 1998. During the past decade, two other nucleoside analogues; entecavir (in 2005) \& telbivudine (in 2006), and two nucleotide analogues; adefovir (in 2002) and tenofovir disoproxil fumarate (in 2008) were licensed.

The ultimate goal of $\mathrm{CHB}$ treatment is to prevent or decrease the development of cirrhosis, hepatic failure and HCC. These endpoints are reached by the suppression of viral replication, which are monitored through parameters such as reduction in HBV DNA to undetectable levels; reduction of serum ALT to normal levels; loss of $\mathrm{HBeAg}$ with or without detection of anti-HBe; and improvement in the histological findings. But, viral eradication is nearly unachievable because of the tendency HBV to integrate into the host genome or remain latent as cccDNA [29]. Considering the extensive cost, the risk of adverse events and the drug resistance with long-term treatment, the most important question that arises is, which $\mathrm{CHB}$ patients need to be treated now and which patients can be monitored and have treatment deferred. And, as the efficacy and the optimal timing to initiate antiviral strategies are greatly influenced by the dynamic course of the disease and the above-mentioned host, viral, and environmental factors associated with progression of $\mathrm{CHB}$; we have tried to focus on the current therapeutic strategies on two separate grounds based on the $\mathrm{HBeAg}$ status.

\section{Optimal management for HBeAg positive chronic hepatitis B patients}

Approach to $\mathrm{HBeAg}$ positive patients for anti-viral therapy (Figure 1):

a) During the high proliferative, low inflammatory phase: As mentioned earlier, these patients usually have persistently normal ALT levels (PNALT) and very high HBV DNA levels without any evidence of liver disease. Studies have also shown low rates of anti-HBe seroconversion in patients who were treated during this phase of the disease [30]. Hence treatment can be deferred in most scenarios. However, the severity of histological lesions varies widely across studies in HBeAg positive patients with PNALT [31]. In these patients, the continued high $\mathrm{HBV}$ replication and a prolonged $\mathrm{HBeAg}$ positive phase can increase the risk of HCC and the progression of liver disease. Hence, it is wise to perform liver biopsy and treat the patients with PNALT after careful consideration of the associated host factors $[1,3]$

- Treatment can be deferred in young patients $<30$ years without any evidence of liver disease and without family history of HCC or cirrhosis. Follow-up every 3-6 months with serum ALT levels and serum HBV DNA levels and every 6-12 months with $\mathrm{HBeAg}$ are advisory.

- Biopsy is recommended in patients $>30$ years with or without family history of HCC or cirrhosis to make therapeutic decisions.

- A positive family history of HCC should however reduce the age limit for any therapeutic decisions.

b) During immune clearance phase: The judgment for initiating treatment in patients during the immune active phase depends majorly on the baseline serum ALT and HBV DNA levels.

- Current guidelines recommend treatment commencement in all patients with baseline ALT > 2 ULN (upper limit of normal) and HBV DNA > $20000 \mathrm{IU} / \mathrm{ml}$, even without the need of biopsy as moderate-severe necroinflammation and significant fibrosis is universally seen in these patients $[1,3]$. 


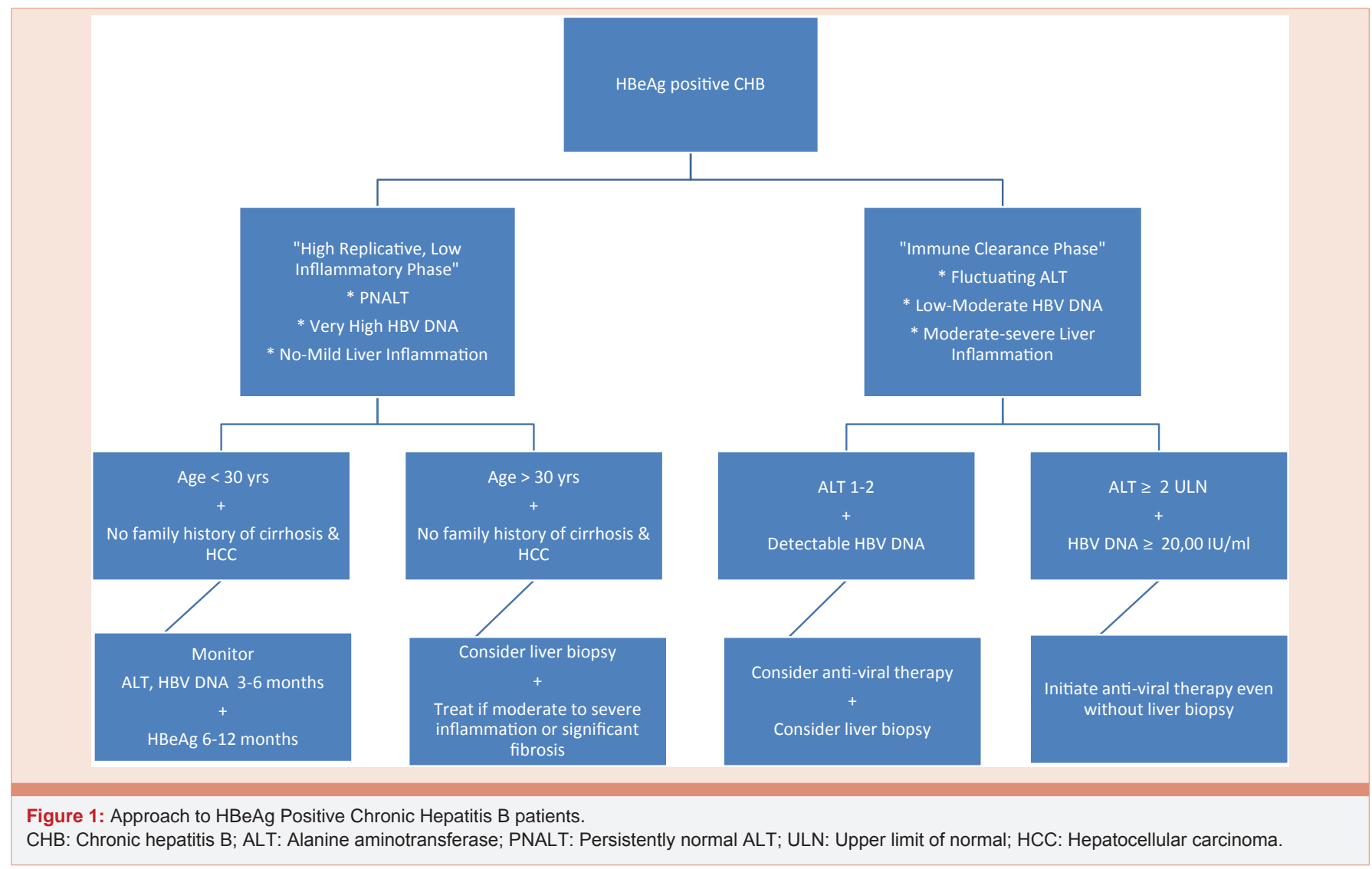

- In patients with ALT between 1-2 ULN, EASL recommend treatment consideration and liver biopsy to assess the severity of liver disease [3]. However, a close follow-up of ALT and HBV DNA levels every 3-6 months for treatment consideration is also being practiced in such patients.

- Age $>40$ years or an increasing or stable HBV DNA for 6 months on follow-up, is a strong recommendation to have a liver biopsy and be started on treatment if there is evidence of moderate-severe necroinflammation and/or significant fibrosis [1]. With decreasing HBV DNA on follow-up regardless of ALT values, these patients can be followed up closely without treatment and wait for spontaneous anti-HBe seroconversion [31].

c) Cirrhotic state: Treatment is generally initiated in all $\mathrm{HBeAg}$ positive $\mathrm{CHB}$ patients with compensated cirrhosis and detectable HBV DNA, even if ALT levels are normal. With any event of decompensation, urgent start of anti-viral therapy is recommended in all patients irrespective of HBV DNA levels and ALT levels $[1,3,4]$.

\section{Role of interferon's in $\mathrm{HBeAg}(+) \mathrm{CHB}$ patients' management:}

a) Standard vs. pegylated IFN: Standard IFNa, which was first drug available for the treatment of $\mathrm{HBeAg}(+) \mathrm{CHB}$ infection, has now been largely replaced by pegylated (PEG)-IFNa. This clinical scenario is chiefly attributed to PEG-IFNa's pharmacokinetic profile of longer half-life, stable serum concentrations and once a week
$180 \mathrm{mcg}$ subcutaneous administrations for 48 weeks, compared to thrice weekly injections of standard INF [32]. Also, studies have stated a greater combined sustained viral response (SVR) rate, defined as combination of HBeAg loss; HBV DNA suppression; and ALT normalization, following a 24-week course of PEG-IFNa-2a compared to standard IFNa-2a [33].

b) End points for Treatment: Though the ideal end point of therapy is HBsAg loss, with or even without seroconversion to antiHBs, studies have indicated a low rate of HBsAg seroconversion of $3-5 \%$ in $\mathrm{HBeAg}(+)$ patients after 6 months of therapy [34,35]. Hence, a more convincing approach would be at targeting a sustained or maintained virological remission (defined as loss of $\mathrm{HBeAg}$ ); virological response (defined as an HBV DNA concentration of less than $2000 \mathrm{IU} / \mathrm{ml}$ ); and biochemical response (defined as normalization of ALT levels).

c) Predictors of response to treatment: Multi-variable analyses of $\mathrm{HBeAg}$ positive $\mathrm{CHB}$ patients treated with $\mathrm{PEG}-\mathrm{IFNa}$ in large international studies have shown that low HBV DNA $\left(<2 \times 10^{8} \mathrm{IU} /\right.$ $\mathrm{ml})$, high ALT ( $>2-5 \mathrm{ULN}$ ), and high activity scores on liver biopsy $(\geq$ A2) are baseline predictors to anti-HBe seroconversion [36]. Also, HBV genotype A with either high ALT or low HBV DNA levels, HBV genotype B \& $\mathrm{C}$ with both high ALT and low HBV DNA levels had a high probability of achieving an SVR at 6months post-treatment $[37,38]$. 
HBsAg: The latest handiness of commercial assays for HBsAg quantification has aided studies to investigate the role of HBsAg levels as a predictor of response to PEG-IFNa. In HBeAg positive CHB patients, not baseline HBsAg levels, but on-treatment HBsAg levels were shown to be a useful predictor of response to PEG-IFNa. Large multicenter trials done in Asian patients with $\mathrm{HBeAg}$ positive $\mathrm{CHB}$, have displayed a high probability of $55 \%$ and $45 \%$ of anti-HBe seroconversion at 6 months post-treatment in subjects who achieved HBsAg levels $<1500 \mathrm{IU} / \mathrm{ml}$ at 12 weeks of PEG-IFNa therapy $[39,40]$. In the same cohort, the cumulative rate of anti-HBe seroconversion at 6 months post-treatment was found to be $0 \%$ and $15 \%$ in subjects who achieved HBsAg levels $>20,000 \mathrm{IU} / \mathrm{ml}$ at 12 weeks of PEG-IFNa therapy. Recently, long-term follow-up studies analyzing the PEGIFNa prediction rules based on $\mathrm{HBs} A g$ levels in $\mathrm{HBeAg}$ positive $\mathrm{CHB}$ patients, have demonstrated a negative predictive value (NPV) of 92 98\% for 12-week stopping rule based on $\mathrm{HBsAg}>20,000 \mathrm{IU} / \mathrm{ml}$ for no response in patients with HBV genotype B or C; NPV of $97-100 \%$ for 12-week stopping rule based on absence of any decline in $\mathrm{HBsAg}$ for no response in patients with HBV genotype A or D; and NPV of nearly $100 \%$ for 24-week stopping rule based on HBsAg >20 $000 \mathrm{IU} /$ $\mathrm{ml}$ for no response in patients irrespective of their genotype status $[40,41]$.

Anti-Hbc: The use of quantitative baseline anti-Hbc as a predicator of response to PEG-INFa has been studied recently. In HBeAg positive cohort treated with PEG-INFa, results have shown an $\mathrm{HBeAg}$ seroconversion rate of $65.8 \%$ in patients with baseline anti$\mathrm{Hbc} \geq 4.4 \log 10 \mathrm{IU} / \mathrm{ml}$ and baseline HBV DNA $<9 \log 10$ copies/ $\mathrm{ml}$, compared to $25.4 \%$ in patients with other baseline characteristics [42]. However in the same cohort, the on-treatment HBsAg levels of $<1500 \mathrm{IU} / \mathrm{ml}$ at 24 weeks of PEG-IFNa therapy, failed to show a predictor response to $\mathrm{HBeAg}$ seroconversion, which is in contrary to the results seen in previous studies. Another study in $\mathrm{HBeAg}$ positive patients, have shown that baseline anti-Hbc can be considered as an independent predictor of response to PEG-INFa therapy. Results showed that, increasing order of the baseline anti-Hbc $(<5,000 \mathrm{IU} /$ $\mathrm{ml}$ to $\geq 50,000 \mathrm{IU} / \mathrm{ml}$ ) was positively correlated with rates of $\mathrm{HBeAg}$ seroconversion $(7.7 \%$ to $52.6 \%)$, virological response rates $(7.7 \%$ to $47.4 \%)$ and combined response rates (7.7\% to $42.1 \%)$ [43]. However, further investigations are required to validate these results.

HBeAg: Despite the lack of standard commercial HBeAg assays, studies have also tried to investigate the role of HBeAg levels as a predictor of response to PEG-IFN. Data from a large phase III trial in patients with $\mathrm{HBeAg}$ positive $\mathrm{CHB}$ treated with PEG-IFNa-2a, exhibited a probability rate of $>50 \%$ of anti-HBe seroconversion at 6 months post-treatment in subjects who achieved HBeAg level $<10$ $\mathrm{PEIU} / \mathrm{ml}$ at 24 weeks of therapy [44]. In the same study, the cumulative rate of anti-HBe seroconversion at 6 months post-treatment was only $4 \%$ in subjects who achieved $\mathrm{HBeAg} \geq 100 \mathrm{PEIU} / \mathrm{ml}$ at 24 weeks of therapy. However, a more recent study has suggested the role of $\mathrm{HBeAg}$ levels as a predictor of response to PEG-IFNa, is influenced by the presence of precore and basic core promoter mutants and hence should not be routinely used for monitoring of PEG-IFNa therapy [45].

However, the application and utility of quantitative measures of
HBsAg and HBeAg are being extensively researched in the field of HBV therapeutics that might provide new dimensions for predictors of response.

d) Efficacy and durability of therapy: Data from large international trials have shown better rates of $\mathrm{HBeAg}$ seroconversion in the order of approximately $30 \%$; at 6 months following 12 months of PEG-IFN, compared to those with shorter duration or with inferior dosage $[34,35]$. However the rates of HBsAg loss and HBV DNA suppression to $<400$ copies $/ \mathrm{ml}$ following 12 months of treatment were only around $3-5 \%$ and $7-14 \%$, respectively.

Durability after anti-HBe seroconversion following PEG-IFNa was very satisfactory with studies showing $83 \%$ of initial responders maintained the serological response at 12 months post-therapy, among which $69 \%$ maintained serum HBV DNA $<10000$ copies/ $\mathrm{ml}$ and $38 \%$ maintained serum HBV DNA $<400$ copies/ml [46]. Also HBsAg negativity was maintained in $30 \%$ of initial responders, after a mean follow-up of 3 years [47].

Role of nucleos(t)ide analogues in $\mathrm{HBeAg}$ positive $\mathrm{CHB}$ patients management:

a) Early vs. late NA's: The advent of nucleos(t)ide analogues (NA's) have revolutionized the management of $\mathrm{CHB}$ infection worldwide; chiefly attributed to its oral administration, potent antiviral activity and lesser side effects. A major drawback of earlier NA's such as lamivudine (3TC) and adefovir was the high rate of antiviral drug resistance. Lamivudine is associated with the highest rate of resistance, increasing with duration of treatment from $14 \%$ - 32\% after 1 year of treatment to as high as $60 \%-70 \%$ after 5 years of continuous therapy $[48,49]$. Primarily, the mutation associated with its resistance involves substitution of methionine in the tyrosine-methionineaspartate-aspartate (YMDD) motif of the HBV DNA polymerase for valine or isoleucine (rtM204V/I, rtV173L) and substitution of methionine by a leucine in an upstream region (rtL180M) [50]. Despite the initial low resistance rate with adefovir, the cumulative resistance rate in a phase III clinical trial in HBeAg-positive patients was estimated to be $20 \%$ after 5 years of continuous therapy [51]. Primary mutations associated with adefovir resistance have been described to be through substitution of threonine by asparagine N236T and valine or threonine substitution by alanine (A181V/T) [52]. In case of telbivudine, though the rate of resistance is lower than 3TC; results from clinical trials have shown that the resistance rate is substantial and increases exponentially after the first year of treatment from 5\% to $25 \%$ at the end of second year itself [53]. To date, only M204I has been observed to be the primary mutation associated with telbivudine resistance [54]. However, the new NA's such as entecavir (ETV) and tenofovir (TDF) have high barriers to resistance. Preliminary data from the studies in NA naïve HBeAg-positive patients, suggest that the rate of entecavir resistance was observed only to be $3.6 \%$ by week 96 and $1.2 \% \%$ after 5 years of treatment $[55,56]$. This resistance to entecavir appears to occur through a two-hit mechanism with initial selection of M204V/I mutation followed by amino acid substitutions at rtT184, rtS202, or rtM250 [57]. Recently, the rate of TDF resistance was reported to be $0 \%$ after 5 years of treatment, in phase 3 trials of NA-naive patients [58].

Apart from the resistance scenario, ETV and TDF were shown 
to be the most potent drugs of all the NA's for suppressing HBV replications in patients with $\mathrm{HBeAg}$ positive $\mathrm{CHB}$ infection. A phase III randomized clinical trial studying ETV and 3TC in patients with compensated liver disease, showed that entecavir resulted in significantly higher rates of undetectable or $<60-80 \mathrm{IU} / \mathrm{ml}$ serum HBV DNA levels (67\% vs. 37\%), normalization of ALT levels (68\% vs. $60 \%)$, and reduction in necroinflammatory activity ( $72 \%$ vs. $62 \%)$, after 48 weeks of treatment [59]. However, the rates of anti-HBe seroconversion were similar between the groups ( $21 \%$ vs. $18 \%)$. In a similar study comparing tenofovir and adefovir response after 48 weeks, the cohort on tenofovir had better rates of undetectable or $<60-80 \mathrm{IU} / \mathrm{ml}$ serum HBV DNA levels (76\% vs. $13 \%$ ), normalization of ALT levels (68\% vs. 54\%), with similar rates of histological response (74\% vs. $68 \%$ ) and HBeAg seroconversion (21\% vs $18 \%$ ) [60]. though limited and inconclusive, data have shown better efficacy rates of ETV and TDF in lamivudine and adefovir resistant HBV infection $[61,62]$. Current scientific guidelines recommend oral administration of entecavir of dose $0.5 \mathrm{mg}$ daily in treatment naïve patients and 1 $\mathrm{mg}$ daily in lamivudine-refractory/resistant patients. The approved dose of tenofovir is $300 \mathrm{mg}$ orally once daily. Both agents' doses should be adjusted for patients with estimated creatinine clearance $50 \mathrm{~mL} / \mathrm{min}[1,3]$. Adefovir, though have demonstrated maximum nephrotoxic potential, its consideration for treatment of $\mathrm{CHB}$ with lower doses have shown better $\mathrm{HBeAg}$ seroconversion rates, HBV DNA suppression, ALT normalization, durability of response and long term outcomes $[51,63]$.

b) Endpoints for treatment: In $\mathrm{HBeAg}$-positive patients treated with NA's, though seroconversion to anti-HBe is a desired intermediate endpoint to stop the treatment, these patients can continue therapy until they achieve HBsAg loss. This end-point is considered to be ideal, as it has been associated with complete and permanent remission of $\mathrm{CHB}$ activity and excellent long-term outcomes.

c) Predictors of response to treatment: Preliminary data suggest that low viral load (HBV DNA $<10^{8} \mathrm{IU} / \mathrm{ml}$ ), high serum ALT levels and high activity scores on liver biopsy are solid pretreatment predictors to anti-HBe seroconversion $[60,64,65]$. The results have been striking with the probability of $\mathrm{HBeAg}$ seroconversion differing greatly from $<1 \%$ in HBeAg positive patients with normal ALT levels, to $30 \%$ to $40 \%$ in patients with ALT levels $>5$-fold the upper normal limit, treated with ETV, LAM or ADV [66].

HBsAg: Also, studies have tried to elucidate the role of decline in HBsAg during NA treatment in determining subsequent $\mathrm{HBeAg}$ or HBsAg loss. In a long-term TDF trial in HBeAg positive patients, HBsAg loss were associated with loss of HBeAg in the first 24 weeks of TDF treatment, high baseline HBsAg levels, an HBsAg slope from baseline to week 12 and an ALT flare in the first 12 weeks of therapy $[67,68]$. However, further studies are required to analyze the role of HBsAg kinetics during NAs therapy.

Anti-HBc: A recent study in a HBeAg positive cohort treated with telbivudine, showed a $\mathrm{HBeAg}$ seroconversion rate of $37.1 \%$ in patients with baseline anti-Hbc $\geq 4.4 \log 10 \mathrm{IU} / \mathrm{ml}$ and baseline HBV DNA $<9 \log 10$ copies/ml, compared to $14.5 \%$ in patients with other baseline characteristics [42]. Also, combined with the on-treatment
HBsAg levels of $<1500 \mathrm{IU} / \mathrm{ml}$ at 24 weeks of NA therapy showed a predictor response of $\mathrm{HBeAg}$ seroconversion $48.6 \%$. Though these predictors have shown positive results, further studies are required in validating its value in predicting the efficacy of NA's.

d) Efficacy and durability of therapy: Phase III clinical trial's outcome have exhibited that prolonged treatment with NA's are associated with increase in the rates of anti-HBe seroconversion. The cumulative rate of anti-HBe seroconversion ranges approximately from $20 \%$ in patients treated with ETV or TDF at 1 year to $40 \%$ at 7 years of TDF therapy [56,69].

However, the durability of anti-HBe seroconversion is questionable in patients treated with NA's, with rates ranging from $40 \%$ to $80 \%$ upon discontinuation of NA therapy $[70,71]$. This disease progression after $\mathrm{HBeAg}$ seroconversion was suggested in a study is due to the emergence of precore and core promoter mutations, which occurs even before HBeAg seroconversion [72]. An overall incidence of core promoter mutations has been reported to be as high as $88.1 \%$ in such patients. These evidences have strongly recommended the clinical practitioners to continue NAs for 12 more months after antiHBe seroconversion, to have a long follow-up after stopping NA's and to maintain persistently low HBV DNA levels, which in specific could be used as predictor of disease progression to either HBeAg-negative $\mathrm{CHB}$ or $\mathrm{HBeAg}$ seroreversion. Evidences also support prolonged treatment with ETV or TDF increase the rate of HBV DNA levels of $<60-80 \mathrm{IU} / \mathrm{ml}$ to almost $100 \%$ with continued maintenance over time $[56,69]$. Rates of HBsAg loss following 1 year of NA's treatment have been less noteworthy ranging from $0-1 \%$ among the less potent NA's such as adefovir, lamivudine, telbivudine to $3-5 \%$ among ETV and TDF $[56,69]$. However, the long-term TDF trial in HBeAg positive patients have shown promising results with respect to cumulative rate of HBsAg loss from $8 \%$ after 3 years of therapy to $12 \%$ after 7 years of therapy [73].

Recent studies involving ETV and TDV in patients with baseline cirrhosis have shown considerate positive impact in prevention of progression of fibrosis and regression of cirrhosis, after 5-6 years of therapy [74,75]. Recently, another large cohort study matched for the risk of HCC with historical controls, showed a reduction in the incidence of HCC with ETV, with higher response rates among patients with risk factors for HCC such as cirrhosis [76]. In a longterm study with TDV, incidence rates of HCC in patients with and without cirrhosis were reported to be $4.5 \%$ and $1.5 \%$ respectively. The salient features of this study are that, the HCC incidence rates in patients without cirrhosis were lower than that predicted by the REACH-B model and this is the first evidence to reveal a positive effect of HCC risk reduction in patients without cirrhosis on NA therapy, which contradicts results of the meta-analysis of 27 trails [77]. Also, earlier randomized controlled trials using lamivudine and adefovir have shown a similar response with clear reduction in complications $[78,79]$.

Selection between PEG-IFNa vs. NA's in HBeAg positive CHB patients' management (Figure 2): The preference between the drug options available for the management of $\mathrm{HBeAg}$ positive CHB patients has to be considered from two viewpoints i.e. patient 
preference and physician preference. Patients generally prefer oral treatment compared to injections; thus, giving NA's which are taken as one tablet per day, an important advantage over PEG-IFN $\alpha$ which are administered weekly as subcutaneous injections. Also several data from clinical trials have shown the excellent tolerance and safety profile of NA's over PEG-INF $\alpha$, which is associated with several contraindications and a wide range of adverse events such as influenza-like illness, anorexia, weight loss, emotional liability etc. $[35,80]$.

Between the ETV and TDF, which are the current first-line NA options, ETV appears to be safer as few studies have reported about the potential nephrotoxicity of long term TDF therapy [81]. However, the rates of decline in creatinine clearance or hypophosphataemia are very low $(<1 \%)$ in CHB patients after 5 years of TDF therapy [75]. Also, it should be noted that except telbivudine, minimal declines in creatinine clearance have been reported with all NAs, requiring dosing adjustments when creatinine clearance is $<50 \mathrm{ml}[1,3]$.

From the physician viewpoint, NA's holds an advantage over PEG-IFN $\alpha$ as its wants less frequent on-treatment monitoring due to its superior safety profile and excellent tolerance levels [34]. Also NA's is applicable in patients at different stages of HBV infection such as chronic hepatitis B, patients with cirrhosis, decompensated patients and in the liver transplant setting with excellent results and easy follow-up. The only drawback of NA's over PEG-INF $\alpha$ is the indefinite time period of therapy, which might pose a threat to its safety profile, raising concerns about compliance and thereby its efficacy [82]. This scenario should be compared to that of the management of noncommunicable diseases such as diabetes mellitus and hypertension, where patient education about adherence to therapy has changed the entire outlook of the disease management. At the same time, physicians should consider PEG-INF $\alpha$ as an attractive option with respect to sustained virological response with finite duration too.

Combination Therapies: Another theoretically attractive concept in managing patients with $\mathrm{CHB}$ infection, is the addition of HBV agents of different mechanism of action or the same action for improving the HBsAg clearance rates. In one randomized controlled study, addition of TDF to ETV in patients with very high baseline viral load of HBV DNA $\geq 108 \mathrm{IU} / \mathrm{ml}$.।, showed a significantly higher viral suppression than ETV therapy alone (70\% vs. 60\%) [83]. Similar results were shown in another study comparing TDF vs. TDF + emitricitabine, however the rates of $\mathrm{HBeAg}$ and $\mathrm{HBsAg}$ clearance were the same [30].

With regards to the efficacy of NA's and PEF-INFa combination therapy in the management of $\mathrm{HBeAg}$ positive $\mathrm{CHB}$ patients, a recent

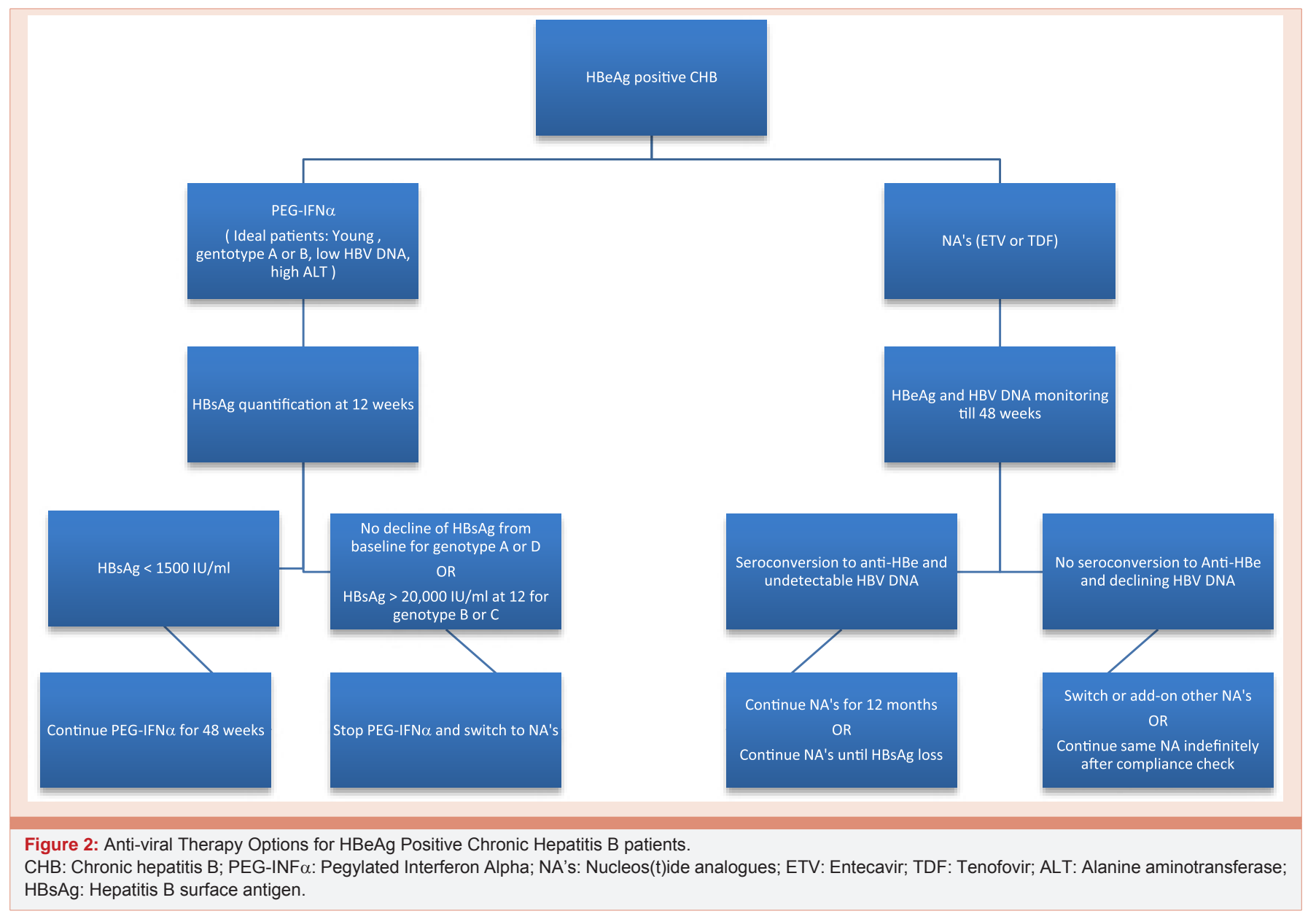


meta-analysis have shown enhanced rates of undetectable HBV-DNA, HBeAg loss and HBsAg loss with no significant difference in ALT normalization, HBsAg seroconversion, and histology improvement, compared NA's monotherapy [84]. In other studies, though higher on-treatment virological response was seen in patients on PEG-IFNa with lamivudine, sustained off-treatment virological or serological response was not any better compared to mono therapies [34,35]. However, it necessitates the need for long-term studies for analyzing the efficacy of combination therapies in future for the management of $\mathrm{HBeAg}$ positive $\mathrm{CHB}$ patients.

Future challenges: Another debatable topic in the management of CHB patients with NA's is with regards to partial virological responders. Partial virological response has been defined as $>1 \log$ $10 \mathrm{IU} / \mathrm{ml}$ decrease in HBV DNA but detectable after at least 6 months of therapy in compliant patients [3]. Recommendations for this scenario, at week 24 in patients receiving lamivudine or telbivudine, or at week 48 in patients receiving adefovir; are to consider changing to either entecavir or tenofovir. However partial responder's to ETV and TDF at week 48 , is managed by experts with the same agent in case of declining HBV DNA kinetics or by adding another agent in case of non-declining HBV DNA kinetics [3]. Recently, the results from a study in treatment naïve $\mathrm{HBeAg}(+) \mathrm{CHB}$ patients on ETV monotherapy have raised concerns about the current guidelines criteria for defining primary non-response on ETV therapy. Primary virological non-response has been defined as $<1$ log decrease after 3 months by EASL or as $<2 \log$ drop after 6 months by AASLD. But, the study results have shown that the rate of primary non-response to be very low and no significant difference in the cumulative rate of virological response between primary responders and non-responders [85]. Several experts have suggested, to increase the on-treatment monitoring for ETV or TDF from the guidelines recommendation of every 3-6 months to 6 months once after patient compliance is confirmed.

\section{Optimal management for HBeAg negative chronic hepatitis $B$ patients}

HBeAg-negative hepatitis B infection is currently the predominant type of $\mathrm{CHB}$ worldwide, especially in the western countries and is more difficult-to-cure with frequent progression to end-stage liver disease and HCC [3].

Approach to $\mathrm{HBeAg}$ negative patients for anti-viral therapy (Figure 3):

a) During the non-replicative or inactive HBV carrier phase: The most vital step in the management of these patients is their differentiation from chronic $\mathrm{HBeAg}$ negative $\mathrm{CHB}$, which requires serial testing of ALT every 3 months and HBV DNA every 3-6 months for at least one year. Current guidelines suggest once you designate a patient as inactive $\mathrm{HBV}$ carrier by absence of HBeAg and presence of anti-HBe, undetectable or low levels of HBV DNA in PCR-based assays, repeatedly normal ALT levels, and minimal or no necroinflammation, slight fibrosis, or even normal histology on biopsy; treatment and liver biopsy can be deferred as their prognosis is usually benign [1,3]. Long-term follow-up of these carriers has indicated that the vast majority shows sustained biochemical remission and very low risk of cirrhosis or HCC [86]. Also, there isn't enough evidence to support any therapy that truly creates an impact on the HBsAg status. Precautions such as family screening, vaccination of the member's negative for HBsAg, protected sexual intercourse, avoidance of alcohol, denial of organ or blood donations and screening with alpha fetoprotein (AFP) and ultrasound (USG)

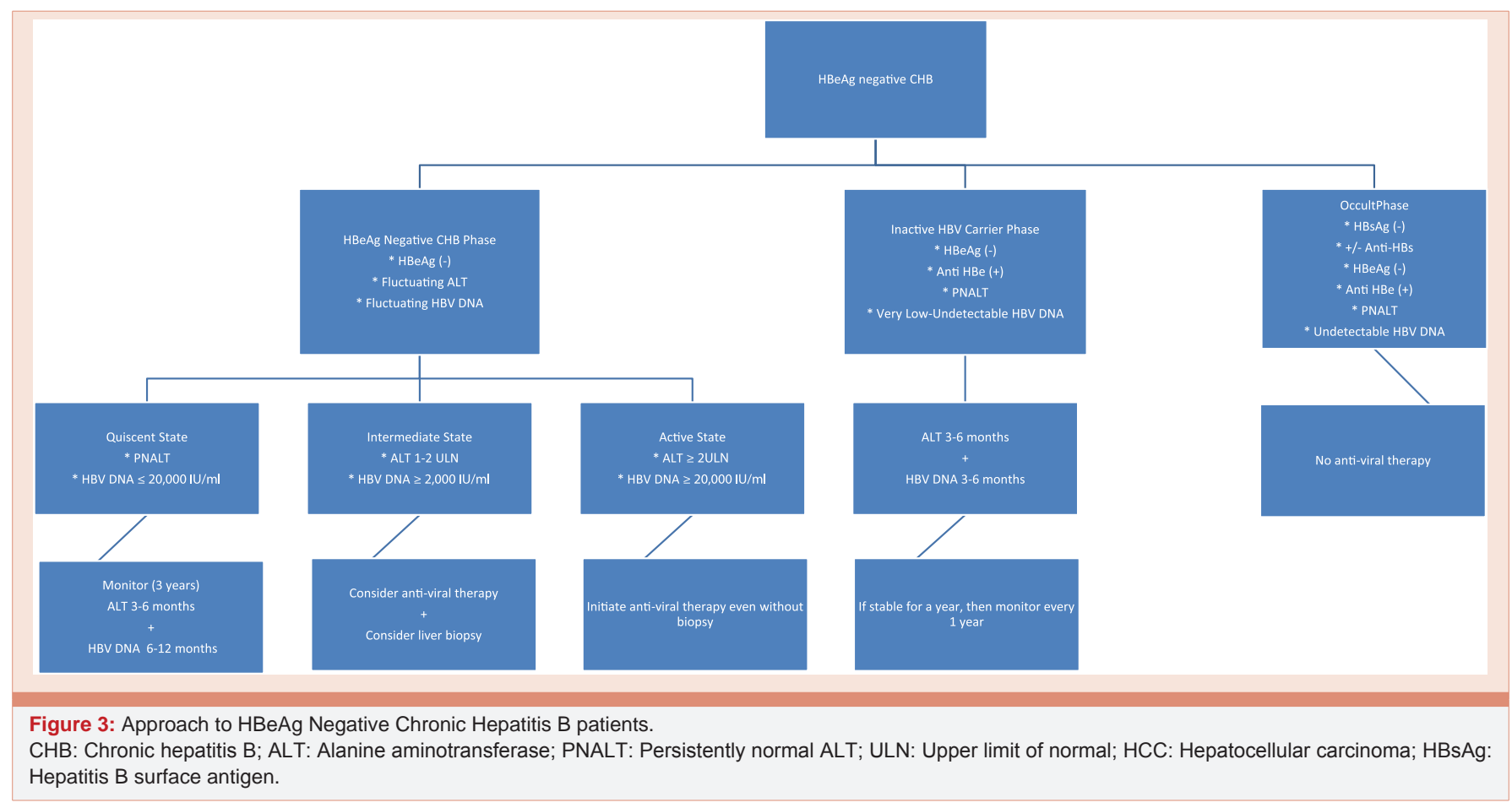


abdomen in case of positive family history of HCC should be undertaken regarding these patients $[1,3]$.

b) During the $\mathrm{HBeAg}$ negative $\mathrm{CHB}$ phase: As mentioned earlier, these patients are characterized by periodic reactivation with a pattern of fluctuating levels of HBV DNA and aminotransferases and active hepatitis and continued necro-inflammation in the liver. The treatment strategy of these patients should also be individualized according to their clinical profile.Active state: AASLD \& EASL clinical guidelines recommend to initiate treatment even without biopsy in all these patients, with persistent ALT $>2$ ULN (upper limit of normal) and HBV DNA $\geq 20000 \mathrm{IU} / \mathrm{ml}[1,3]$. However, APASL guidelines differ little by having HBV DNA $\geq 2000 \mathrm{IU} / \mathrm{ml}$ as the cutoff to the similar picture [4]. A liver biopsy or fibroscan should be followed to rule out cirrhosis, although it has no say on the treatment strategy.

- Intermediate state: In patients with ALT 1-2 ULN and HBV DNA $\geq 2000 \mathrm{IU} / \mathrm{ml}$, all guidelines recommend treatment consideration and liver biopsy. In patients with no to mild histological disease, treatment can be deferred $[1,3,4]$.

- Quiescent state: Histologically significant liver disease is rare in HBeAg-negative patients with persistently normal ALT levels (PNALT) defined by 3 normal ALT readings 3 months apart and serum HBV DNA $\leq 20,000 \mathrm{IU} / \mathrm{ml}$. Current guidelines recommend close follow-up without treatment in all these patients in the $\mathrm{HBeAg}$ negative $\mathrm{CHB}$ phase, without any evidence of liver disease [1,3]. The mandatory close follow-up involves ALT monitoring every 3 months and HBV DNA every 6-12 months for at least 3 years. After the follow-up period of 3 years, these patients can be managed like inactive chronic HBV carriers with fibroscan to evaluate the severity of fibrosis.

Cirrhotic state: Treatment is generally initiated in HBeAg negative $\mathrm{CHB}$ patients with compensated cirrhosis and HBV DNA $\geq$ $2000 \mathrm{IU} / \mathrm{ml}$ even if ALT levels are normal [1,3]. However, treatment should also be considered in patients with compensated cirrhosis with HBV DNA < $2000 \mathrm{IU} / \mathrm{ml}$, if ALT is elevated. AASLD and EASL guidelines recommend urgent start of anti-virals in patients with decompensated cirrhosis and detectable HBV DNA [1,3]. Whereas, APASL recommend treatment in decompensated cirrhotic patients irrespective of HBV DNA levels [4]

\section{Role of interferon's in HBeAg (-) CHB patient's management:}

a) Standard vs. pegylated IFN: The usage of Standard IFNa for the $\mathrm{HBeAg}$ negative $\mathrm{CHB}$ patients has been substituted by PEG-IFNa because of the previously mentioned enhanced pharmacokinetic profile such as longer half-life, absence of wide fluctuations in serum concentrations, once a week subcutaneous injections, thereby improving compliance, reducing adverse events and enhancing viral suppression $[1,3]$.

b) Endpoints for treatment: In HBeAg negative patients, though ultimate endpoint is sustained off-therapy HBsAg loss with or without anti-HBs, sustained off-therapy undetectable HBV DNA levels and ALT normalization are shown to be associated with improved prognosis $[1,3]$. c) Predictors of response to treatment: Since only a minority of $\mathrm{HBeAg}$ negative patients treated with PEG-IFNa achieved sustained virological response and for its side-effect profile, it is indispensable to identify the patients who are likely to benefit from treatment based on certain baseline parameters [87]. Earlier studies have showed enough evidence about high baseline ALT, low baseline HBV DNA, younger age and female gender being independent predictors of response to PEG-IFNa [88]. However the major challenge about these predictors is associated with the natural phase of chronic HBeAg negative infection, where the liver enzymes and viremia tends to fluctuate, making the already defined baseline predictors very unreliable. Recent interest is in the genetic testing for IL28B polymorphisms to prioritize $\mathrm{CHB}$ patients for IFN-based therapy. Some authors showed that in genotype D HBeAg-negative CHB patients; the IL28B rs12979860 genotype CC patients had better rates of SVR and HBsAg clearance than the non-CC patients [89]. However contradictory results were reported in other studies concluding polymorphisms near the IL28B gene were not associated with on- and post-treatment kinetics of HBV DNA and HBsAg levels, or with 24-week posttreatment responses [90].

HBsAg: On the other hand, with the availability of Architect HBsAg assay (Abbott Diagnostics, Abbott Park, IL, USA) and the Elecsys HBsAg II quant assay (Roche Diagnosticks, Indianapolis, IN, USA), there is increasing evidence on the role of baseline HBsAg and its kinetics during treatment as a predictor of a sustained response. Existing data suggests that baseline HBsAg level below $400 \mathrm{IU} / \mathrm{ml}$ is associated HBsAg loss with corresponding positive predictive value (PPV) of $100 \%$ and a negative predictive value (NPV) of $95 \%$ [91]. However, HBsAg variations according to the natural course of infection and HBV genotypes have proposed genotype-specific time frames and specific end-of-treatment thresholds to improve responseguided treatment of HBeAg-negative CHB [92,93]. The on-treatment decline in HBsAg > $0.5 \log 10$ at week 12 and $>1 \log 10 \mathrm{IU} / \mathrm{ml}$ at week 24 have shown a $89 \%$ and $92 \%$ chance of SVR, with corresponding $10 \%$ chance in patients who failed to achieve this decline $[94,95]$. Also, studies have stated patients with no decline of HBsAg levels and a decrease of HBV DNA of $<2 \log 10$ copies $/ \mathrm{ml}$ at week 12 predicts non-response in genotype D HBeAg negative patients treated with PEG-IFNa [96]. The results of the stopping rule had a NPV of $100 \%$ and were confirmed by several other reports [97]. This application of early stopping rule optimizes the effectiveness of PEG-IFNa therapy by avoiding unnecessary treatment in patients with HBeAg-negative CHB (genotype D) who have no chance of achieving a sustained response.

d) Efficacy and durability of therapy: Initial cohort studies in HBeAg-negative $\mathrm{CHB}$, which used 12 or 24-month courses of standard IFNa therapy have showed biochemical and virological responses in $22-30 \%$ of patients with $>40$ clearing HBsAg $[98,99]$. Subsequent studies with 48 -week course of PEG-IFNa-2a have been reported to induce SVR off-therapy in approximately $36-43 \%$ patients with rates of HBsAg clearance increasing from $3 \%$ at end of therapy to $9 \%$ and $12 \%$ after a follow-up of 3 and 5 years, respectively [100].

Recent data suggest that HBeAg negative genotype D patients could benefit from extending therapy beyond 48 weeks [101]. 
Randomized controlled study in $128 \mathrm{HBeAg}$ negative $\mathrm{CHB}$ patients (94\% genotype D) showed that patients treated with PEG-IFNa-2a for 96 weeks, compared to those treated with PEG-IFNa-2a for 48 weeks had better rates HBV DNA <2000 IU/ml (29\% vs. $12 \%)$ and HBsAg clearance $(5.8 \%$ vs. $0 \%)$ [102]. Also, the application of extended use PEG-IFNa in the management of $\mathrm{HBeAg}$ negative genotype $\mathrm{D}$ patients was supported by studies showing no significant difference in tolerance levels, adverse events and discontinuation rate between the two groups [102].

Role of NA's in the management of HBeAg negative $\mathrm{CHB}$ patients:

a) Early vs. late NA's: Among the NA's, entecavir (ETV) or tenofovir (TDF), are the first-line drugs recommended for treatmentnaïve $\mathrm{HBeAg}$ negative chronic hepatitis $\mathrm{B}$ patients. These agents are not only potent than other existing NA's, but also has high barrier to resistance.

Studies have reported the cumulative probability of developing resistance to lamivudine increased over the period of time in $\mathrm{HBeAg}$ negative patients, from $10 \%$ after 1 year of therapy to as high as $63 \%$ after 5 years of therapy [103]. Also, it resulted in a progressively lower rate of undetectable $\mathrm{HBV}$ from $73 \%$ at 1 year to $34 \%$ at 4 years and ALT normalization from $84 \%$ to $36 \%$ [104]. A phase III clinical trial including $\mathrm{HBeAg}$ negative $\mathrm{CHB}$ patients, reported significantly higher rates of histologic responses $(70 \%$ vs. $61 \%)$, undetectable HBV DNA levels (90\% vs. $72 \%$ ) and ALT normalizations (78\% vs. $71 \%)$ in subjects on ETV compared to 3TC [105]. Another study reported that the relapse rate was very high $(>90 \%)$ after 1 year of stoppage of 3TC [106]. Studies analyzing the cumulative probability of developing resistance to adefovir have shown a similar picture to lamivudine, with increasing resistance over the period of time in $\mathrm{HBeAg}$ negative patients, from $0 \%$ after 1 year of therapy to $11 \%$ and $29 \%$ after 3 and 5 years of therapy, respectively [107]. In a phase III clinical trial, patients on TDF reported significantly higher rates of undetectable HBV DNA levels (93\% vs. 63\%) compared to patients on adefovir [108]. Also, switching to tenofovir resulted in further virus suppression in the patients originally treated with adefovir. Though telbivudine response rates have better than $3 \mathrm{TC}$ in the phase III clinical trials, genotypic resistance after 1 and 2 years of treatment was still observed in $2.3 \%$ and $10.8 \%$ of HBeAg-negative patients who received telbivudine [109]. The earlier NA's 3TC and adefovir had another drawback of holding the durability of response as studies have reported the rate to be $<10 \%$ in $\mathrm{HBeAg}(-)$ individuals $[110,111]$.

b) Endpoints for treatment: Since HBV eradication or clearance of HBsAg is almost impossible with NA's; a more realistic aim is the normalization of ALT activity, persistent inhibition or at least significant suppression of $\mathrm{HBV}$ replication and prevention of cirrhosis and HCC.

c) Predictors of response to treatment: In contrast to $\mathrm{HBeAg}$ positive $\mathrm{CHB}$ treatment, evidences showing the baseline predictors of response to NA's in the management of patients with $\mathrm{HBeAg}(-) \mathrm{CHB}$ are not widely available [112]. At the same time, HBV genotype does not influence the virological response to any NA. However, these agents are preferred over PEG-IFN in patients with more severe liver disease, in older patients, and those who do not respond, unwilling to take or have contraindications to PEG-IFNa.

d) Efficacy and durability of therapy: The efficacy of ETV and TDF has been very remarkable in the management of treatment naïve $\mathrm{HBeAg}$ negative $\mathrm{CHB}$ patients. European field practice studies including $1162 \mathrm{CHB}$ patients treated with ETV have reported the cumulative probability of achieving a virological response at year 5 as $97 \%$ and $99 \%$ [113]. Similar efficacy reports were seen in Asian studies, where $98 \%$ and $95 \%$ of patients on ETV achieved undetectable HBV DNA at year 5 [114-116]. The rate of ETV resistance was also very low $(<1 \%)$, that were managed with substitution to TDF. TDFregistration trials have reported that the rates of undetectable HBV DNA ranges from 92 to $100 \%$ from 3 to 7 year course of TDF therapy, with no resistance reported in any of their patients [117].

Partial virological response to ETV or TDF is very rare. Studies have shown that it acceptable to treat with same drug if the residual viremia is $\leq 1000 \mathrm{IU} / \mathrm{ml}$ and to consider a switch strategy of substituting TDF for partial response to ETV and vice versa, only if residual viremia is $>1000 \mathrm{IU} / \mathrm{ml}$ or a flat pattern in serum HBV DNA levels is seen [118]. Despite its efficacy, the rates of HBsAg loss following 12 months of ETV or TDF are close to zero [119,120]. Long-term effective ETV and TDF treatment have been shown to induce regression of fibrosis in two-thirds of patients with cirrhosis, especially in all compensated patients, thereby preventing clinical decompensation [121,122]. Also, in patients with decompensated liver disease, survival was significantly improved because of persistent HBV DNA suppression. In Asian and European studies, the annual incidence of HCC in patients with cirrhosis receiving ETV and TDF was reported to range from $2-4 \%$ and $3.7-4 \%$ respectively, and in patients without cirrhosis it ranged from $0.6-1.4 \%$ and $0.4-1 \%$ respectively $[123,124]$. Long-term administration of ETV or TDF was also associated with low rates of severe AEs and drug discontinuation. [125].

Selection between NA's and PEG-INF in HBeAg negative patient's treatment (Figure 4): TDF and ETV are the only treatment options for patients with severe liver disease, elderly patients, or those with contraindications to or unwilling to take PEG-IFNa as well as those with certain severe associated diseases. However, long-term administration of ETV or TDF cannot eradicate HBV making longterm therapy necessary in most patients, increasing the cost, creating compliance issues and unproven safety profiles. The finite course of PEG-IFN is still an impressive strategy in patients who are young with high ALT levels and low HBV DNA and appropriate virus genotype.

a) Combination therapies: Combination therapies are starting to become the future possible options in the management of $\mathrm{HBeAg}$ negative CHB patients. Earlier studies involving PEG-IFN with 3TC or adefovir have shown a higher on-treatment virological response rate but no benefit in of treatment SVR or serological response [126]. In PARC trail, the addition of ribavirin did not improve the efficacy of a 48-week course with PEG-IFNa offering similar rates of combined responses at 6 months [127]. A promising approach to improve HBsAg clearance rates could be the add-on or switch to PEG-IFNa therapy among the responders to NA's [128]. There have been promising results in small studies evaluating this approach 


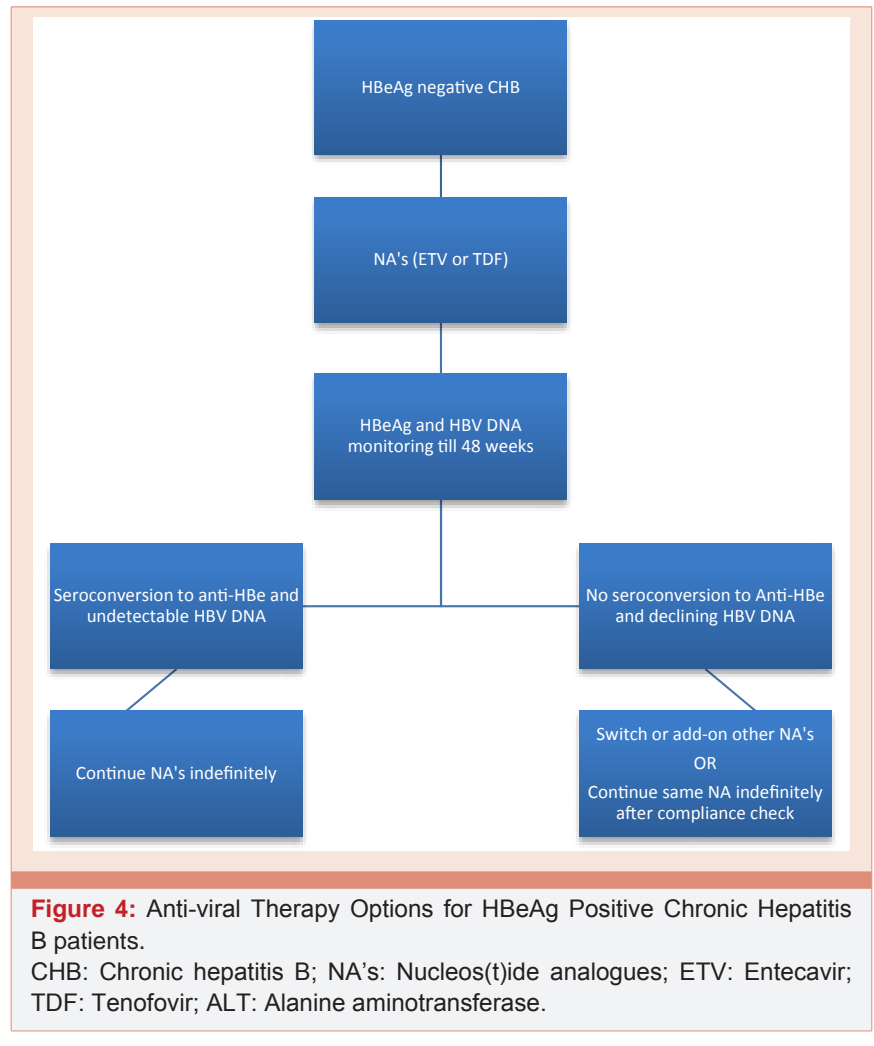

[129]. In one study adefovir was given for 20 weeks and was followed by adefovir and PEG-IFNa for 4 weeks and finally PEG-IFNa alone for 44 weeks. Twenty-four weeks after the end of PEG-IFNa, 50\% had either partial (HBV DNA $<10000$ copies/ml) or complete (HBV DNA $<70$ copies/ml) virological response [130]. In another study, the SVR (HBV DNA <2000 IU/ml) was significantly higher in patients treated with telbivudine first followed by PEG-IFNa than vice versa $(46.7 \%$ vs. $13.3 \%, \mathrm{P}=0.046)$ [131]. Following a slightly different concept, few patients with PEG-IFNa added to a stable and effective NA therapy, showed a rapid decline in HBsAg resulting in anti-HBs development at weeks 32 or 40 [132]. These preliminary results suggest that the combined use of NAs and PEG-IFN $\alpha$ may be effective, but need further studies to reveal their potential benefits and determine whether they are worth pursuing.

\section{Conclusion}

Currently, the existing therapeutic strategies for the management of patients with chronic hepatitis B infections are the pegylated IFNa and nucleos(t)ide analogues. Among these, entecavir (ETV) and tenofovir (TDF) are most the favored treatment options in both $\mathrm{HBeAg}$ positive and $\mathrm{HBeAg}$ negative patients, as they can be used in all chronic HBV patients and are more convenient to use for its oral administration, excellent tolerance, good safety profile and minimal or no risk of long-term resistance. Despite their virological, biochemical and histological benefits in nearly all-adherent patients, $\mathrm{HBV}$ eradication is not possible and hence the risk of HCC, resulting in long or indefinite periods of therapy. In the future, novel therapeutic targets or creative combination therapies of adding a finite course of PEG-IFNa to NA's might be desirable to increase the sustained virological response rates, achieve $\mathrm{HBV}$ eradication or at least substantially increase the rates of HBsAg loss and seroconversion.

\section{References}

1. Lok AS, McMahon BJ (2009) Chronic hepatitis B: update 2009. Hepatology 50: 661-662

2. Ott JJ, Stevens GA, Groeger J, Wiersma ST (2012) Global epidemiology of hepatitis B virus infection: new estimates of age-specific HBsAg seroprevalence and endemicity. Vaccine 30: 2212-2219.

3. European Association for the Study of the Liver (2012) EASL Clinical Practice Guidelines: management of chronic hepatitis B virus infection. J Hepatol 57: 167-185.

4. Liaw YF, Kao JH, Piratvisuth T, Chan HL, Chien RN, et al. (2012) AsianPacific consensus statement on the management of chronic hepatitis B: a 2012 update. Hepatol Int 6: 531-561.

5. Block TM, Gish R, Guo H, Mehta A, Cuconati A, et al. (2013) Chronic hepatitis B: what should be the goal for new therapies? Antiviral Res 98: 27-34.

6. Gish RG, Given BD, Lai CL, Locarnini SA, Lau JY, et al. (2015) Chronic hepatitis B: Virology, natural history, current management and a glimpse at future opportunities. Antiviral Res 121: 47- 58.

7. Hong M, Sandalova E, Low D, Gehring AJ, Fieni S, et al. (2015) Trained immunity in newborn infants of HBV-infected mothers. Nat Commun 6: 6588.

8. Bertoletti A, Kennedy PT (2015) The immune tolerant phase of chronic HBV infection: new perspectives on an old concept. Cell Mol Immunol 12: 258-263.

9. Liaw YF, Chu CM, Su IJ, Huang MJ, Lin DY, et al. (1983) Clinical and histological events preceding hepatitis $\mathrm{B}$ e antigen seroconversion in chronic type B hepatitis. Gastroenterology 84: 216-219.

10. Livingston SE, Simonetti JP, Bulkow LR, Homan CE, Snowball MM, et al. (2007) Clearance of hepatitis $B$ e antigen in patients with chronic hepatitis $B$ and genotypes A, B, C, D, and F. Gastroenterology 133: 1452-1457.

11. Sugauchi F, Orita E, Ichida T, Kato H, Sakugawa H, et al. (2003) Epidemiologic and virologic characteristics of hepatitis B virus genotype B having the recombination with genotype C.Gastroenterology 124: 925-932.

12. Hussain M, Chu CJ, Sablon E, Lok AS (2003) Rapid and sensitive assays for determination of hepatitis B virus (HBV) genotypes and detection of HBV precore and core promoter variants. J Clin Microbiol 41: 3699-3705.

13. Naoumov NV, Schneider R, Grotzinger T, Jung MC, Miska S, et al. (1992) Precore mutant hepatitis B virus infection and liver disease. Gastroenterology 102: $538-543$.

14. Sanchez-Tapias JM, Costa J, Mas A, Bruguera M, Rodes J (2002) Influence of hepatitis $B$ virus genotype on the long-term outcome of chronic hepatitis $B$ in western patients. Gastroenterology 123: 1848-1856.

15. Shi YH (2012) Correlation between hepatitis B virus genotypes and clinical outcomes. Jpn J Infect Dis 65: 476-482.

16. Wiegand J, Hasenclever D, Tillmann HL (2008) Should treatment of hepatitis $B$ depend on hepatitis B virus genotypes? A hypothesis generated from an explorative analysis of published evidence. Antivir Ther 13: 211-220.

17. Tran TT, Trinh TN, Abe K (2008) New complex recombinant genotype of hepatitis B virus identified in Vietnam. J Virol 82: 5657-5663.

18. Sunbul M (2014) Hepatitis B virus genotypes: global distribution and clinical importance. World J Gastroenterol 20: 5427-5434.

19. Chang MH, Hsu HY, Hsu HC, Ni YH, Chen JS, et al. (1995) The significance of spontaneous hepatitis $\mathrm{B}$ e antigen seroconversion in childhood: with special emphasis on the clearance of hepatitis B eantigen before 3 years of age. HEPATOLOGY 22: 1387-1392

20. Bowyer SM, Sim JG (2000) Relationships within and between genotypes of hepatitis $B$ virus at points across the genome: footprints of recombination in certain isolates. J Gen Virol 81: 379-392. 
21. Liaw YF, Chen YC, Sheen IS, Chien RN, Yeh CT, et al. (2004) Impact of acute hepatitis $C$ virus superinfection in patients with chronic hepatitis $B$ virus infection. Gastroenterology 126: 1024-1029.

22. Negro F (2014) Hepatitis D virus coinfection and superinfection. Cold Spring Harb Perspect Med 4: a021550

23. Fattovich G, Giustina G, Christensen E, Pantalena M, Zagni I, et al. (2000) Influence of hepatitis delta virus infection on morbidity and mortality in compensated cirrhosis type B. The European Concerted Action on Viral Hepatitis (Eurohep). Gut 46: 420-426.

24. Soriano V, Puoti M, Bonacini M, Brook G, Cargnel A, et al. (2005) Care of patients with chronic hepatitis $B$ and HIV co-infection: recommendations from an HIV-HBV International Panel. AIDS 19: 221-240.

25. Bondini S, Kallman J, Wheeler A, Prakash S, Gramlich T, et al. (2007) Impact of non-alcoholic fatty liver disease on chronic hepatitis B. Liver Int 27: 607611

26. Bosch FX, Ribes J, Cleries R, Diaz M (2005) Epidemiology of hepatocellular carcinoma. Clin Liver Dis 9: 191-211.

27. Yang HI, Yeh SH, Chen PJ, lloeje UH, Jen CL, et al. (2008) Associations between hepatitis $B$ virus genotype and mutants and the risk of hepatocellular carcinoma. J Natl Cancer Inst 100: 1134-1143.

28. Yapali S, Talaat N, Lok AS (2014) Management of hepatitis B: our practice and how it relates to the guidelines. Clin Gastroenterol Hepatol 12: 16-26.

29. Laras A, Koskinas J, Dimou E, Kostamena A, Hadziyannis SJ (2006) Intrahepatic levels and replicative activity of covalently closed circular hepatitis B virus DNA in chronically infected patients. Hepatology 44: 694

30. Chan HL, Chan CK, Hui AJ, Chan S, Poordad F, et al. (2014) Effects of tenofovir disoproxil fumarate in hepatitis $B$ e antigen-positive patients with normal levels of alanine aminotransferase and high levels of hepatitis $B$ virus DNA. Gastroenterology 146: 1240-1248.

31. Papatheodoridis GV (2013) Hepatitis B virus treatment: which patients can have treatment deferred? Clin Liv Dis 2: 15-17.

32. Papatheodoridis GV, Manolakopoulos S, Dusheiko G, Archimandritis AJ (2008) Therapeutic strategies in the management of patients with chronic hepatitis B. Lancet Infect Dis 8: 167-178.

33. Vlachogiannakos J, Papatheodoridis GV (2015) Optimal therapy of chronic hepatitis B: how do I treat HBeAg-positive patients? Liver Int 35: 100-106.

34. Lau GK, Piratvisuth T, Luo KX, Marcellin P, Thongsawat S, et al. (2005) Peginterferon Alfa-2a, lamivudine, and the combination for HBeAg-positive chronic hepatitis B. N Engl J Med 352: 2682-2695.

35. Janssen $\mathrm{HL}$, van Zonneveld M, Senturk $\mathrm{H}$, Zeuzem S, Akarca US, et al. (2005) Pegylated interferon alfa-2b alone or in combination with lamivudine for HBeAg-positive chronic hepatitis B: a randomised trial. Lancet 365: 123 129

36. Buster EH, Hansen BE, Lau GK, Piratvisuth T, Zeuzem S, et al. (2009) Factors that predict response of patients with hepatitis B e antigen-positive chronic hepatitis B to peginterferon-alfa. Gastroenterology 137: 2002-2009.

37. Flink HJ, Van ZM, Hansen BE, De Man RA, Schalm SW, et al. (2006) Treatment with Peg-interferon alpha-2b for HBeAg-positive chronic hepatitis $\mathrm{B}$ : HBsAg loss is associated with HBV genotype. Am J Gastroenterol 101 297-303.

38. Wiegand J, Hasenclever D, Tillmann HL (2008) Should treatment of hepatitis $B$ depend on hepatitis B virus genotypes? A hypothesis generated from an explorative analysis of published evidence. Antivir Ther 13: 211-220.

39. Gane E, Jia J, Han K, Tanwandee T, Chuang WL, et al. (2011) Neptune study: on-treatment HBsAg level analysis confirms prediction of response observed in phase 3 study of peginterferon alfa-2a in $\mathrm{HBeAg-positive}$ patients. J Hepatol 54: S31.
40. Sonneveld MJ, Hansen BE, Piratvisuth T, Jia JD, Zeuzem S, et al. (2013) Response-guided peginterferon therapy in hepatitis $B$ e antigen-positive chronic hepatitis B using serum hepatitis B surface antigen levels. Hepatology 58: $872-880$.

41. Lo AO, Wong VW, Wong GL, Chan HL, Dan YY (2015) Cost-effectiveness of response-guided therapy with peginterferon in the treatment of chronic hepatitis B. Clin Gastroenterol Hepatol 13: 377-385.

42. Fan R, Sun J, Yuan Q, Xie Q, Bai X, et al. (2015) Baseline quantitative hepatitis $B$ core antibody titre alone strongly predicts $\mathrm{HBeAg}$ seroconversion across chronic hepatitis $\mathrm{B}$ patients treated with peginterferon or nucleos(t)ide analogues. Gut pii: gutjnl-2014-308546

43. Hou FQ, Song LW, Yuan Q, Fang LL, Ge SX, et al. (2015) Quantitative hepatitis $B$ core antibody level is a new predictor for treatment response in $\mathrm{HBeAg-positive} \mathrm{chronic} \mathrm{hepatitis} \mathrm{B} \mathrm{patients} \mathrm{receiving} \mathrm{peginterferon.}$ Theranostics 5: 218-226.

44. Fried MW, Piratvisuth T, Lau GK, Marcellin P, Chow WC, et al. (2008) $\mathrm{HBeAg}$ and hepatitis $\mathrm{B}$ virus DNA as outcome predictors during therapy with peginterferon alfa-2a for $\mathrm{HBeAg}$-positive chronic hepatitis $\mathrm{B}$. Hepatology 47 : 428-434

45. Sonneveld MJ, Rijckborst V, Zwang L, Zeuzem S, Jenny Heathcote E, et al. (2013) Hepatitis B e antigen levels and response to peginterferon: influence of precore and basal core promoter mutants. Antiviral Res 97: 312-317.

46. Piratvisuth T, Lau G, Chao YC, Jin R, Chutaputti A, et al. (2008) Sustained response to peginterferon alfa-2a $(40 \mathrm{kD})$ with or without lamivudine in Asian patients with $\mathrm{HBeAg}$-positive and HBeAgnegative chronic hepatitis $\mathrm{B}$. Hepatol Int 2: 102-110.

47. Buster EH, Flink HJ, Cakaloglu Y, Simon K, Trojan J, et al. (2008) Sustained $\mathrm{HBeAg}$ and HBsAg loss after long-term follow-up of HBeAg-positive patients treated with peginterferon alpha-2b. Gastroenterology 135: 459-467.

48. Dienstag JL, Schiff ER, Wright TL, Perrillo RP, Hann HW, et al. (1999) Lamivudine as initial treatment for chronic hepatitis B in the United States. New Engl J Med 341: 1256-1263.

49. Chang TT, Lai CL, Chien RN, Guan R, Lim SG, et al. (2004) Four years of lamivudine treatment in Chinese patients with chronic hepatitis B. J Gastroenterol Hepatol 19: 1276-1282.

50. Locarnini S (2005) Molecular virology and the development of resistant mutants: implications for therapy. Semin Liver Dis 25: 9-19.

51. Marcellin P, Chang TT, Lim SG, Sievert W, Tong M, et al. (2008) Long-term efficacy and safety of adefovir dipivoxil for the treatment of hepatitis $B$ e antigen-positive chronic hepatitis B. Hepatology 48: 750-758.

52. Angus P, Vaughan R, Xiong S, Yang H, Delaney W, et al. (2003) Resistance to adefovir dipivoxil therapy associated with the selection of a novel mutation in the HBV polymerase. Gastroenterology 125: 292-297.

53. Lai CL, Gane E, Liaw YF, Hsu CW, Thongsawat S, et al. (2007) Telbivudine versus lamivudine in patients with chronic hepatitis B. N Engl J Med 357: 2576-2588

54. Lai CL, Leung N, Teo EK, Tong M, Wong F, et al. (2005) A 1-year trial of telbivudine, lamivudine, and the combination in patients with hepatitis $B$ e antigen-positive chronic hepatitis B. Gastroenterology 129: 528-536.

55. Gish RG, Lok AS, Chang TT, de Man RA, Gadano A, et al. Entecavir therapy for up to 96 weeks in patients with HBeAg-positive chronic hepatitis B. Gastroenterology 2007; 133(5): 1437-1444.

56. Chang TT, Lai CL, Kew Yoon S, Lee SS, Coelho HS, et al. (2010) Entecavir treatment for up to 5 years in patients with hepatitis $B$ e antigen-positive chronic hepatitis B. Hepatology 51: 422-430.

57. Tenney DJ, Levine SM, Rose RE, Walsh AW, Weinheimer SP, et al. (2004) Clinical emergence of entecavir-resistant hepatitis $B$ virus requires additional substitutions in virus already resistant to Lamivudine. Antimicrob Agents Chemother 48: 3498-3507. 
58. Marcellin P, Gane E, Buti M, Afdhal N, Sievert W, et al. (2013) Regression of cirrhosis during treatment with tenofovir disoproxil fumarate for chronic hepatitis B: a 5-year open-label follow-up study. Lancet 381: 468-475.

59. Chang TT, Gish RG, De Man R, Gadano A, Sollano J, et al. (2006) A comparison of entecavir and lamivudine for HBeAg-positive chronic hepatitis B. N Engl J Med 354: 1001-1010.

60. Marcellin P, Heathcote EJ, Buti M, Gane E, de Man RA, et al. (2008) Tenofovi disoproxil fumarate versus adefovir dipivoxil for chronic hepatitis B. N Engl J Med 359: 2442-2455.

61. Sherman M, Yurdaydin C, Simsek H, Silva M, Liaw YF, et al. (2008) Entecavir therapy for lamivudinerefractory chronic hepatitis B: improved virologic, biochemical, and serology outcomes through 96 weeks. Hepatology 48: 99108

62. Choe WH, Kwon SY, Kim BK, Ko SY, Yeon JE, et al. (2008) Tenofovir plus lamivudine as rescue therapy for adefovir-resistant chronic hepatitis B in hepatitis B e antigen-positive patients with liver cirrhosis. Liver Int 28: 814820 .

63. Wu IC, Shiffman ML, Tong MJ, Marcellin P, Mondou E, et al. (2008) Sustained hepatitis $B$ e antigen seroconversion in patients with chronic hepatitis $B$ after adefovir dipivoxil treatment: analysis of precore and basal core promoter mutants. Clin Infect Dis 47: 1305-1311.

64. Liaw YF, Gane E, Leung N, Zeuzem S, Wang Y, et al. (2009) 2-Year GLOBE trial results: telbivudine is superior to lamivudine in patients with chronic hepatitis B. Gastroenterology136: 486-495.

65. Perrillo RP, Lai CL, Liaw YF, Dienstag JL, Schiff ER, et al. (2002) Predictors of HBeAg loss after lamivudine treatment for chronic hepatitis B. Hepatology 36: 186-194.

66. Buster EH, Hansen BE, Lau GK, Piratvisuth T, Zeuzem S, et al. (2009) Factors that predict response of patients with hepatitis $B$ e antigen positive chronic hepatitis B to peginterferon-alfa. Gastroenterology 137: 2002-2009.

67. Lee JM, Ahn SH, Kim HS, Park H, Chang HY, et al. (2011) Quantitative hepatitis $\mathrm{B}$ surface antigen and hepatitis $\mathrm{B}$ e antigen titers in prediction of treatment response to entecavir. Hepatology 53: 1486-1493.

68. Heathcote EJ, Marcellin P, Buti M, Gane E, De Man RA, et al. (2011) HBsAg kinetics in patients with chronic hepatitis $\mathrm{B}(\mathrm{CHB})$ treated with tenofovir disoproxil fumarate (TDF) for up to 4 years. J Hepatol 54: S297.

69. Marcellin P, Gane E, Buti M, Afdhal N, Sievert W, et al. (2013) Regression of cirrhosis during treatment with tenofovir disoproxil fumarate for chronic hepatitis B: a 5-year open-label follow-up study. Lancet 381: 468-475.

70. Reijnders JG, Perquin MJ, Zhang N, Hansen BE, Janssen HL (2010) Nucleos(t)ide analogues only induce temporary hepatitis B e antigen seroconversion in most patients with chronic hepatitis B. Gastroenterology 139: $491-498$.

71. Wang Y, Thongsawat S, Gane EJ, Liaw YF, Jia J, et al. (2013) Efficacy and safety of continuous 4-year telbivudine treatment in patients with chronic hepatitis B. J Viral Hepat 20: e37-46.

72. Yuan HJ, Ka-Ho WD, Doutreloigne J, Sablon E, Lai CL, et al. (2007) Precore and core promoter mutations at the time of HBeAg seroclearance in Chinese patients with chronic hepatitis B J Infection 54: 497-503.

73. Heathcote EJ, Marcellin P, Buti M, Gane E, De Man RA, et al. (2011) Threeyear efficacy and safety of tenofovir disoproxil fumarate treatment for chronic hepatitis B. Gastroenterology 140: 132-143.

74. Schiff ER, Lee SS, Chao YC, Kew YS, Bessone F, et al. (2011) Long-term treatment with entecavir induces reversal of advanced fibrosis or cirrhosis in patients with chronic hepatitis B. Clin Gastroenterol Hepatol 9: 274-276.

75. Chang TT, Liaw YF, Wu SS, Schiff E, Han KH, et al. (2010) Long-term entecavir therapy results in the reversal of fibrosis/cirrhosis and continued histological improvement in patients with chronic hepatitis B. Hepatology 52 886-893.
76. Hosaka T, Suzuki F, Kobayashi M, Seko Y, Kawamura Y, et al. (2013) Longterm entecavir treatment reduces hepatocellular carcinoma incidence in patients with hepatitis B virus infection. Hepatology 58: 98-107.

77. Lai CL, Yuen MF (2013) Prevention of hepatitis B virus-related hepatocellular carcinoma with antiviral therapy. Hepatology 57: 399-408.

78. Dienstag JL, Goldin RD, Heathcote EJ, Hann HW, Woessner M, et al. (2003) Histological outcome during long-term lamivudine therapy. Gastroenterology 124: 105-117.

79. Liaw YF, Sung JJ, Chow WC, Farrell G, Lee CZ, et al. (2004) Lamivudine for patients with chronic hepatitis B and advanced liver disease. N Engl J Med 351: 1521-1531.

80. Wursthorn K, Jung M, Riva A, Goodman ZD, Lopez P, et al. (2010) Kinetics of hepatitis $B$ surface antigen decline during 3 years of telbivudine treatment in hepatitis $B$ e antigen-positive patients. Hepatology 52: 1611-1620.

81. Verhelst D, Monge M, Meynard JL, Fouqueray B, Mougenot B, et al. (2002) Fanconi syndrome and renal failure induced by tenofovir: a first case report. Am J Kidney Dis 40: 1331-1333.

82. Fontana RJ (2009) Side effects of long-term oral antiviral therapy for hepatitis B. Hepatology 49: S185-195.

83. Lok AS, Trinh H, Carosi G, Akarca US, Gadano A, et al. (2012) Efficacy of entecavir with or without tenofovir disoproxil fumarate for nucleos(t)ide-naive patients with chronic hepatitis B. Gastroenterology 143: 619-628.

84. Wei W, Wu Q, Zhou J, Kong Y, You H (2015) A Better Antiviral Efficacy Found in Nucleos(t)ide Analog (NA) Combinations with Interferon Therapy than NA Monotherapy for HBeAg Positive Chronic Hepatitis B: A Meta-Analysis. Int J Environ Res Public Health 12: 10039-10055.

85. Yang YJ, Shim JH, Kim KM, Lim YS, Lee HC (2014) Assessment of current criteria for primary nonresponse in chronic hepatitis $B$ patients receiving entecavir therapy. Hepatology 59: 1303-1310.

86. Hsu YS, Chien RN, Yeh CT, Sheen IS, Chiou HY, et al. (2002) Long-term outcome after spontaneous HBeAg seroconversion in patients with chronic hepatitis B. Hepatology 35: 1522-1527.

87. Vlachogiannakos J, Papatheodoridis GV (2014) HBeAg-negative chronic hepatitis B: why do I treat my patients with pegylated interferon-alfa? Liver Int 34: 127-132.

88. Bonino F, Marcellin P, Lau GK, Hadziyannis S, Jin R, et al. (2007) Predicting response to peginterferon alpha-2a, lamivudine and the two combined for HBeAg-negative chronic hepatitis B. Gut 56: 699-705.

89. Lampertico P, Viganò M, Cheroni C, Facchetti F, Invernizzi F, et al. (2013) IL28B polymorphisms predict interferon-related HBsAg seroclearance in genotype $\mathrm{D}$ HBeAg negative patients with chronic hepatitis $\mathrm{B}$. Hepatology 57 : 890-896.

90. Brouwer WP, Arends P, Rijkborst V, et al. (2013) Polymorphisms near the IL28B gene are not associated with response to peginterferon in $\mathrm{HBeAg}$ negative chronic hepatitis B patients. J Hepatol 58: S299.

91. Takkenberg RB, Jansen L, de Niet A, Zaaijer HL, Weegink CJ, et al. (2013) Baseline hepatitis B surface antigen ( $\mathrm{HBsAg}$ ) as a predictor of sustained $\mathrm{HBsAg}$ loss in chronic hepatitis B patients treated with peginterferon alfa-2a and adefovir. Antivir Ther 18: 895-904.

92. Moucari R, Martinot-Peignoux M, Mackiewicz V, Boyer N, Ripault MP, et al. (2009) Influence of genotype on hepatitis B surface antigen kinetics in hepatitis $\mathrm{B}$ e antigen-negative patients treated with pegylated interferon-a2a. Antivir Ther 14: 1183-1188.

93. Brunetto MR, Marcellin P, Cherubini B, Yurdaydin C, Farci P, et al. (2013) Response to peginterferon alfa-2a (40KD) in HBeAg-negative CHB: ontreatment kinetics of HBsAg serum levels vary by HBV genotype. J Hepatol 59: 1153-1159.

94. Moucari R, Mackiewicz V, Lada O, Ripault MP, Castelnau C, et al. (2009) Early serum BsAg drop: a strong predictor of sustained virological response 
to pegylated interferon alfa-2a in HBeAgnegative patients. Hepatology 49: 1151-1157.

95. Brunetto MR, Moriconi F, Bonino F, Lau GK, Farci P, et al. (2009) Hepatitis B virus surface antigen levels: a guide to sustained response to peginterferon alfa-2a in HBeAg-negative chronic hepatitis B. Hepatology 49: 1141-1150.

96. Rijckborst V, Hansen BE, Cakaloglu Y, Ferenci P, Tabak F, et al. (2010) Early on-treatment prediction of response to peginterferon alfa-2a for $\mathrm{HBeAg}$ negative chronic hepatitis B using HBsAg and HBV DNA levels. Hepatology 52: 454-461.

97. Rijckborst V, Hansen BE, Ferenci P, Brunetto MR, Tabak F, et al. (2012) Validation of a stopping rule at week 12 using HBsAg and HBV DNA for HBeAg-negative patients treated with peginterferon alfa- 2a. J Hepatol 56: 1006-1011.

98. Manesis EK, Hadziyannis SJ (2001) Interferon-alpha treatment and retreatment of hepatitis $B$ e antigennegative chronic hepatitis $B$. Gastroenterology 121: 101-109.

99. Lampertico P, Del Ninno E, Viganò M, Romeo R, Donato MF, et al. (2003) Long-term suppression of hepatitis $B$ e antigen-negative chronic hepatitis $B$ by 24-month interferon therapy. Hepatology 37: 756-763.

100. Marcellin P, Lau GK, Bonino F, Farci P, Hadziyannis S, et al. (2004) Peginterferon alfa- $2 a$ alone, lamivudine alone, and the two in combination in patients with HBeAg-negative chronic hepatitis B. N Engl J Med 351: 1206-1217.

101. Gish RG, Lau DT, Schmid P, Perrillo R (2007) A pilot study of extended duration peginterferon alfa-2a for patients with hepatitis $B$ e antigen-negative chronic hepatitis B. Am J Gastroenterol 102: 2718-2723.

102. Lampertico P, Viganò M, Di Costanzo GG, Sagnelli E, Fasano M, et al. (2013) Randomized study comparing 48 and 96 weeks peginterferon a-2a therapy in genotype D HBeAg-negative chronic hepatitis B. Gut 62: 290 298.

103. Hadziyannis SJ, Papatheodoridis GV, Dimou E, Laras A, Papaioannou C (2000) Efficacy of long-term lamivudine monotherapy in patients with hepatitis $B$ e antigen-negative chronic hepatitis B. Hepatology 32: 847-851.

104.Papatheodoridis GV, Dimou E, Dimakopoulos K, Manolakopoulos S, Rapti I, et al. (2005) Outcome of hepatitis B e antigen-negative chronic hepatitis B on long-term nucleos(t)ide analog therapy starting with lamivudine. Hepatology 42: 121-129.

105. Lai CL, Shouval D, Lok AS, Chang TT, Cheinquer H, et al. (2006) Entecavir versus lamivudine for patients with $\mathrm{HBeAg-negative} \mathrm{chronic} \mathrm{hepatitis} \mathrm{B}$. N Engl J Med 354: 1011-1020.

106. Santantonio T, Mazzola M, lacovazzi T, Miglietta A, Guastadisegni A, et al. (2000) Long-term follow-up of patients with anti-HBe/HBV DNA-positive chronic hepatitis $B$ treated for 12 months with lamivudine. J Hepatol 32: $300-$ 306.

107. Hadziyannis SJ, Tassopoulos NC, Heathcote EJ, Chang TT, Kitis G, et al (2006) Long-term Therapy With Adefovir Dipivoxil for HBeAg-Negative Chronic Hepatitis B for up to 5 Years. Gastroenterology 131: 1743-1751.

108. Marcellin P, Heathcote EJ, Buti M, Gane E, de Man RA, et al. (2008) Tenofovir disoproxil fumarate versus adefovir dipivoxil for chronic hepatitis B. N Engl J Med 359: 2442-2455.

109. Liaw YF, Gane E, Leung N, Zeuzem S, Wang Y, et al. (2009) 2-Year GLOBE trial results: telbivudine is superior to lamivudine in patients with chronic hepatitis B. Gastroenterology 136: 486-495.

110.Fung SK, Wong F, Hussain M, Lok AS (2004) Sustained response after a 2-year course of lamivudine treatment of hepatitis $B$ e antigen-negative chronic hepatitis B. J Viral Hepat 11: 432- 438.

111. Schiff E, Lai CL, Hadziyannis S, Neuhaus P, Terrault N, et al. (2007) Adefovir dipivoxil for wait-listed and post-liver transplantation patients with lamivudine-resistant hepatitis B: final long-term results. Liver Transpl 13: 349-360.
112. Viganò $M$, Invernizzi $F$, Lampertico $P$ (2015) Optimal therapy of chronic hepatitis B: how do I treat my HBeAg-negative patients? Liver Int 35: $107-$ 113.

113. Arends P, Sonneveld MJ, Zoutendijk R, Carey I, Brown A, et al. (2014) Entecavir treatment does not eliminate the risk of hepatocellular carcinoma in chronic hepatitis B: limited role for risk scores in Caucasians. Gut 64 1289-1295.

114. Ono A, Suzuki F, Kawamura Y, Sezaki H, Hosaka T, et al. (2012) Longterm continuous entecavir therapy in nucleos(t)ide-naive chronic hepatitis $B$ patients. J Hepatol 57: 508-514.

115. Luo J, Li X, Wu Y, Lin G, Pang Y, et al. (2013) Efficacy of entecavir treatment for up 5 years in nucloes(t)ide-naive chronic hepatitis $B$ patients in real life. Int J Med Sci 10: 427-433.

116. Seto WK, Lam YF, Fung J, Wong DK, Huang FY, et al. (2014) Changes of HBsAg and HBV DNA levels in Chinese chronic hepatitis B patients after 5 years of entecavir treatment. J Gastroenterol Hepatol 29: 1028-1034.

117. Pageaux GP, Zoulim F, Causse X, Larrey D, Ouzan D, et al. (2014) P1061 Long-term treatment with tenofovir in treatment-naive or experienced $\mathrm{CHB}$ patients is effective and well tolerated in real-life practice: 3 years results of the VIREAL study. J Hepatol 60: S430.

118. Lampertico P, Vigano M, Colombo M (2012) Partial response to entecavir and tenofovir in naive patients with chronic hepatitis B: clinical relevance and management. Curr Hepatitis Rep 11: 90-94.

119. Lai CL, Shouval D, Lok AS, Chang TT, Cheinquer H, et al. (2006) Entecavir versus lamivudine for patients with $\mathrm{HBeAg}$-negative chronic hepatitis $\mathrm{B}$. N Engl J Med 354: 1011-1020.

120. Marcellin P, Heathcote EJ, Buti M, Gane E, de Man RA, et al. (2008) Tenofovir disoproxil fumarate versus adefovir dipivoxil for chronic hepatitis B. N Engl J Med 359: 2442-2455.

121.Zoutendijk R, Reijnders JG, Zoulim F, Brown A, Mutimer DJ, et al. (2013) Virological response to entecavir is associated with a better clinical outcome in chronic hepatitis B patients with cirrhosis. Gut 62: 760-765.

122. Lim YS, Han S, Heo NY, Shim JH, Lee HC, et al. (2014) Mortality, liver transplantation, and hepatocellular carcinoma among patients with chronic hepatitis B treated with entecavir vs lamivudine. Gastroenterology 147: 152161.

123. Wong GL, Chan HL, Chan HY, Tse PC, Tse YK, et al. (2013) Accuracy of risk scores for patients with chronic hepatitis $\mathrm{B}$ receiving entecavir treatment. Gastroenterology 144: 933-944.

124. Cho JY, Paik YH, Sohn W, Cho HC, Gwak GY, et al. (2014) Patients with chronic hepatitis $B$ treated with oral antiviral therapy retain a higher risk for HCC compared with patients with inactive stage disease. Gut 63: 19431950

125. Manns MP, Akarca US, Chang TT, Sievert W, Yoon SK, et al. (2012) Longterm safety and tolerability of entecavir in patients with chronic hepatitis $B$ in the rollover study ETV-901. Expert Opin Drug Saf 11: 361-368.

126. Piccolo P, Lenci I, Demelia L, Bandiera F, Piras MR, et al. (2009) A randomized controlled trial of pegylated interferon-alpha2a plus adefovir dipivoxil for hepatitis $\mathrm{B}$ e antigen negative chronic hepatitis B. Antivir Ther 14: 1165-1174.

127. Rijckborst V, ter Borg MJ, Cakaloglu Y, Ferenci P, Tabak F, et al. (2010) A randomized trial of peginterferon alpha-2a with or without ribavirin for HBeAg-negative chronic hepatitis B. Am J Gastroenterol 105: 1762-1769.

128. Manesis EK, Papatheodoridis GV, Tiniakos DG, Hadziyannis ES, Agelopoulou OP, et al. (2011) Hepatitis B surface antigen: relation to hepatitis $B$ replication parameters in $\mathrm{HBeAg}$-negative chronic hepatitis $\mathrm{B} . \mathrm{J}$ Hepatol 55: 61-68.

129. Reijnders JG, Rijckborst V, Sonneveld MJ, Scherbeijn SM, Boucher CA, et al. (2011) Kinetics of hepatitis B surface antigen differ between treatment with peginterferon and entecavir. J Hepatol 54: 449- 454. 
130. Moucari R, Boyer N, Ripault MP, Castelnau C, Mackiewicz V, et al. (2011) Sequential therapy with adefovir dipivoxil and pegylated interferon alfa-2a for HbeAg-negative patients. J Viral Hepat 18: 580-586.

131. Piccolo P, Lenci I, di Paolo D, Demelia L, Sorbello O, et al. (2013) A randomized controlled trial of sequential pegylated interferon-a and telbivudine or vice versa for 48 weeks in hepatitis B e antigen-negative chronic hepatitis B. Antivir Ther 18: 57-64.

132. Kittner JM, Sprinzl MF, Grambihler A, Weinmann A, Schattenberg JM, et al. (2012) Adding pegylated interferon to a current nucleos(t)ide therapy leads to HBsAg seroconversion in a subgroup of patients with chronic hepatitis B. J Clin Virol 54: 93-95. 